\title{
RESPONSE OF THREE RICE CULTIVARS TO SEED CLASSES AND SOME SEED SOAKING TREATMEANTES EL-Kalla, S. E. ${ }^{*}$; A. M. Salama* and S. E. Helal ${ }^{* *}$ and El-Shimaa E.I. Mostafa ${ }^{* \star}$ *Agron. Dept., Fac. of Agric., Mansoura Univ., Egypt. \\ ${ }^{*}$ Seed Technology and Training Center -Agricultueral Research Station.
}

\begin{abstract}
Three rice cultivars (Giza 178, Sakha 101 and Sakha 104) under five seed soaking treatments (water, $\mathrm{ZnSO}_{4} 2 \%, \mathrm{Di}$ ammonium phosphate $\{\mathrm{DAP}\} 2 \%, \mathrm{GA}_{3}$ $120 \mathrm{mg} / \mathrm{L}$, and cytokinine $75 \mathrm{mg} / \mathrm{L}$ ) with using two seed classes (Basic seed and Certified seed) are studied in two field experiments at El-Senblawin Dakahlia Governorate during 2011 and 2012 seasons.

The aim of this study was to investigate the performance of identify three rice cultivars studying the genetic purity of tested varieties through the basic and certified seed classes under five soaking treatments on growth and yield of rice.

The obtained results could be summarized as follows:

Giza 178 cultivar and Sakha104 significantly surpassed the local cultivar Sakha101 in all studied characters in both seasons.

Using basic seed class recorded the highest values of plant height, number of tillers/hill, number of grains /panicle, grain weight /panicle, 1000-grain weight, grain yield /fed in both seasons. While, the certified Sowing seed produced the highest values of panicle length in both seasons.

The obtained results showed significant effect at seed soaking in both seasons. The seed soaking $\mathrm{ZnsO}_{4}$ significantly increased plant height, number of tillers/hill, number of grains/panicle, panicle weight $(\mathrm{g})$ and1000 grain weight in both seasons.

The interaction among Giza 178, basic seed class and seed soaking znso 4 gave the highest values of plant height, number of tillers/hill, panicle length, number of grains/panicle (g), grains/panicle (g), 1000 grain weight, and grain yield (t/fed) of rice.
\end{abstract}

\section{INTRODUCTION}

Rice (Oryza sativa L.) is a cereal crop and major source of income for a large number of peoples. In Egypt, rice is playing a major role in food security and we need to produce rice with self sufficiency and exported to improve the national income. Increasing rice productivity can be achieved through using high yielding cultivars and optimizing the cultural practices such as seed classes and seed soaking treatments. Introduction of Sakha 104 rice cultivar increased the yields about $15-20 \%$ more than the promising high yielding commercial cultivar.

Giza 178 and Sakah 104 cultivar significantly reported better panicle length, number of panicles/hill, filled grains/panicle, panicle weight,1000-grain weight and grain yield EL-Kalla et al 2006,Zayed et al., 2006 than the local cultivar Sakha101 in both seasons.

Production of certified seed involves the use two classes of seeds the basic seed, and certified seed (Douglas 1980). 
Zayed et al (2005) ,Bassiouni et al (2011) reported that seed soaking in the terms of per-sowing chemicals seed treatments such as Gibberllic acid(GA3) ,diammonium phosphate (DAP) and zinc sulphate (ZnSo4) could invigorate the rice seedling and improved its quality and increased rice Abd-EL Hafaz et al. (2005) showed that the1000 -grain weight decressed with increasing the doses of GA3 where the application with doses of GA3 increased the seed set percentage but reduced the high grain filling rate EL-Ekhtyar et al. (2008) staudied the pre sowing seed treatment by GA3, Znso4, cytokine 75 ,DAP . GA3 gave the highest values of panicle number, panicle weight, number of filled grain 1000 grain weight and grain. Howover znso4, cytokinne 75 and control treatment did not significantly vary in threir effect for straw yield.

\section{MATERIALS AND METHODS}

Two field experiments were carried out at EL-Senblawin Center,Dakahlia Governorate, during 2011 and 2012 summer seasons to study performance of three rice cultivares ,i,e Giza 178 ,Sakha101, Sakha104 and studing the genetic puriety of tested varities through seed classes (basic and certified ) and the five seed soaking water, Znso42\%, Di ammounum phosphate( DAP) 2\%,GA3 $120 \mathrm{mg} / \mathrm{L}$, cytokinine $75 \mathrm{mg} / \mathrm{L}$

On growth, yield and its components of rice cultivars

The experments were carried out in split plot desien with four replications.

1-The main plots were devoted to the three rice cultivars as follow:-

$$
\text { 1-Giza } 178 \quad \text { 2-Sakha } 101 \quad 3 \text {-Sakha } 104
$$

2-The sub-plots were allocated to the two seed classes as follows: -

1-Basic seed 2-Certified seed

3- The sub-sub -plots were allocated to the five treatments as follows:-

1-Water 2-Znso42\% 3-Di ammounum phosphate( DAP) 2\%

4- $\mathrm{GA}_{3} 120 \mathrm{mg} / \mathrm{L} \quad$ 5- Cytokinine $75 \mathrm{mg} / \mathrm{L}$

The seed were obtained from the Agricultural Research Center (ARC), Ministry of Agriculture and Land Reclamation.

The experimental plot area was $3.0 \mathrm{~m}$ width and $3.5 \mathrm{~m}$ length, resulted

plot area of $10.5 \mathrm{~m}^{2}$ (1/400 fed) The preceding winter crop was wheat (Triticum aestivum valgare) in the two seasons. The soil was clay in texture and having a pH of 8.2 and 7.99 in 2011 and 2012 seasons.,respectivly

Data recorded

A -Quantitative Plant Characteristics:

1- Plant height $(\mathrm{cm}$.) 2- Number of tillers/hill

$B$-panicle characteristics and grain yield:

At harvest, the following parameters were recorded:

1- Panicle length $(\mathrm{cm}) \quad 2-$ Number of grains/panicle

3- Grains weight/panicle (g) 4- 1000- grain weight (g).

$5-$ Grain yield (ton/fed) 


\section{Statistical analysis:}

The Split -Split plot design dopted in this study was permitted the statistical analysis of the data by the technique of analysis of variance (ANOV) in order to observe treatments effects were real and discernible from chance effects, the null hypothesis was tested by ' $F$ ' test in case where test revealed significant among treatments new significant differences (N.L.S.D) at $5 \%, 1 \%$ level of probability compared to elucidate the nature and magnitude of the treatment effect. (Waller and Duncan 1969)

\section{RESULTS AND DISCUSSION}

\section{1-Quantitative plant characteristics: plant height}

Results in Table 1 indicated that plant height was not significantly varied by the evaluated cultivars in the two growing seasons. However, plant height was not markedly affected by cultivars performance in both years Plant height of Giza 178 surpassed Sakha 101 and 104 in both seasons. In other words, plant height averages were 90.6 and $92.9 \mathrm{~cm}$ for Giza 178 cultivar and 87.2 and $85.9 \mathrm{~cm}$ for Sakha101cultivar in the first and second seasons, respectively. Moreover, Sakha 104 cultivar ranked the second in this concern recording values of 88.2 and $90.4 \mathrm{~cm}$ in the first and second seasons, respectively. The increase in Giza 178 cultivar plant height over Sakha101 cultivar might be due to the genetic variation. These results are in accordance with those obtained by El-Refaee (2002), El-Sheref et al. (2004), Singh (2005) and El-Kalla et al. (2006).

Data inTable 1 indicated that there were significant differences between the two studied seed classes on the plant height only in the first season, however this variation was not significant in the second season. Basic seed classes exceeded the certified seed in plant height. However, the tallest plants $(87.9$ and $89.4 \mathrm{~cm})$ were recorded with the basic seed class and the shortest plants(81.4and 89.1)were recorded with the certified seed classes. During 2011 and 2012 season respectively. Similar results were stated by Sedeek (2001).and Draz etal(2003)

The statistical analysis of data revealed that plant height was highly significantly affected by seed soaking treatments in both seasons, as shown in Table 1.Soaking rice seeds in Zinc sulplhate $\left(\mathrm{ZnSO}_{4}\right)$ resulted in significant increase on plant height, compared with the other seed soaking treatments. which produced the highest values of plant height (93.8and $91.4 \mathrm{~cm}$ in the first and second seasons, respectively). Soaking rice seeds with cytokinine at $75 \% \mathrm{mg} / \mathrm{l}$ markedly reduced rice plant height as compared with the other treatments The result indicated to the role of $\mathrm{ZnSO}_{4}$ in increasing plant height of rice. Similar results were stated by Ahmad et al.(2008),Hasanuzzaman et al. (2009).

\section{Number of tillers /hill}

The results in Table 1 indicated that number of tillers/hill was significantly affected by studied cultivars in the two growing seasons. Number of tillers/hill significantly increased with Giza 178 cultivar as compared with 
local cultivar Sakha101 and Sakha104 in both seasons. in other words, number of tillers/hill averages were 9.6 and 8.8 with Giza 178 cultivar and 7.3 and7.8 with Sakha101cultivar in the first and second seasons respectively, the increase in number of tillers/hill by planting Giza 178 cultivar over Sakha101cultivar might be due to the genetic make up factors and consequently increased number of tillers/hill. These results are in accordance with those obtained by Kalboch (1997), Sedeek(2001) and Abd El-Hamed (2002).

The data indicated that there were significant differences between seed classes on the number of tillers/hill . in the fist only The maximum values (8.5) was recorded with using the basic seed. But, the lowest values were (7. 7)with useing the certified seed in 2011 Similar results were stated by Sedeek(2001)

The statistical analysis of data indicate that number of tillers/hill was significantly affected by seed soaking in first season as shown in Table 1 Rice seed soak at zinc sulphate ( $\left.\mathrm{ZnSO}_{4}\right)$ significantly increased number of tillers/hill as compared with other soaking treatment which produced the highest value, 9.5 in the first season, Similar results were stated by Ahmad et al. (2008), and Hasanuzzaman et al. (2009).

\section{Number of grains/panicle}

The obtained results clearly show that studied cultivars significantly affected number of grains/panicle in the second growing season only .Giza 178 cultivar significantly superior than the local cultivar sakha101 in number of grains/panicle in the secand season However no marked differences were detected between Giza 178 and Sakha 101 cultivar. The highest number of grains/panicle were resulted from. Giza 178 cultivar, which were 98.7 and 101. 9 in the first and second seasons, respectively. The former results might be related to genetic factors which resulted from genetic make up relations for the varieties. These results are in good agreement with those stated byAbo-Youssef et al $(201$

The data in Table 1 indicated that there were highly significant differences between seed classes on the number of grains/panicle only in the first season. The maximum values (98.3and 90.3) were recorded with useing the basic seed.But, the lowest values was (82.8and 84.0) with using the certified seed in2011and 2012 seasons,, respectively.These results showed that, The basic seed class was highly similarity than the other seed classes, because the variance value of certified seed was higher than the value in basic seed. Similar results were stated by Sedeek( 2001)

The statistical analysis of data indicated that number of grains/panicle was significantly affected by seed soaking in both seasons as shown in Table 1 seed soaking in of zinc sulphate $\left(\mathrm{ZnSO}_{4}\right)$ significantly increased number of grains/panicle as compared with other soaking treatments In the first season ,water and GA3 seed soaking come in the secand rank and markedly out yielded more number of grains/panicle compered with DAP and cytokinin However in the second season, seed soaking in cytokinin come in the second rank after $\mathrm{ZnSO}_{4}$ Similar results were stated by Ahmad et al. (2008), Hasanuzzaman et al. (2009). 


\section{Grains weight/panicle (g)}

The obtained results showed that studied cultivars Giza 178 cultivar Sakha104 and Sakha 101 significantly affected grains weight/panicle in the first seasons only Giza 178 cultivar significantly was superior than the local Sakha104 in grains weight/panicle in both seasons. Therefore, the highest grains/panicle (2.8 and $3.6 \mathrm{~g})$ were resulted from Giza 178 in the first and second seasons, respectively. The differences among the tested cultivars. could be attributed to the genetic constitution of these cultivars..Similar results were obtained by Abd Allah (1996) and Kalboch (1997)

The data indicated that there were signifant differences between seed classes on the grains weight/panicle. in Table 1. The maximum values 3. 4 and $2.8 \mathrm{~g}$ were recorded with using the basic seed. But the lowest values were 2. 6 and $2.5 \mathrm{~g}$ with using the certified seed in 2011 and 2012 seasons, respectively., Moreover, the basic seed class was highly similarity than the other seed classes, because the variance value of certified seed was higher than the value in basic seed. Similar results were stated by Sedeek (2001)

The statistical analysis of data indicated that grains weight/panicle was significantly affected by seed soaking treatments in first and second seasons as shown in Table 1 Rice seed soaking in ZnSo4 significantly increased grains weight/panicle as compared with other soaking treatments. The highest values, were recorded with $\mathrm{ZnSO}_{4}$ which were 3.9 and $2.5 \mathrm{~g}$ in the first and second seasons, respectively. These results might be due to the role of ZnSo4 in plant Similar results were stated by Bassal and Zahran (2002).

\section{0 grain weight:}

Sakha 104 and Sakha101 and Giza 178 cultivars were not significantly differed regarding 1000 - grain weight in btth seasons as cleared in Table 1

The data indicated that there were significant differences and between seed classes on the 1000 - grain weight in the second season. The maximum values 21.8 and 23.7 were recorded with using the basic seed. But, the lowest values were 21 . 4and $22.9 \mathrm{~g}$ with useing the certified seed in 2011 and 2012 seasons, respectively. The basic seed class was significant than the certified seed classes, because the variance value of certified seed was higher than the value in basic seeds Similar results were stated by Sedeek (2001)

The statistical analysis of data indicate that 1000-grain weight was significantly affected by seed soaking in the first and the second seasons as shown in Table 1. Seed soaking in ZnSo4 significantly increased 1000 - grain weight as compared with other seed soaking which produced the highest values, which were ( 24.4 and $23.4 \mathrm{~g}$ ) in the first and second seasons, respectively These results are in agreement with those found by Bassal and Zahran (2002) and Ahmad et al. (2008).

With respect to the effect of the interaction between rice cultivars and seed classes on 1000- grain weight, the results in Table 2 clearly show that 1000 -grain weight significantly affected by the interaction between rice cultivars and seed classes in both seasons. The results showed that basic seed of Sakha 104 variety recorded the heaviest 1000-grain weight in both seasons, which was $(23.9 \mathrm{~g})$ in the first season and the certified seed sat 


\section{EL-Kalla, S. E. et al.}

sakah 104 possesd the heaviest seeds in the second season(23.99), Non significant differences were observed between the basic and certified seed of Sakha 101 variety in both seasons On the other hand, the certified seed of Giza 178 variety recorded the lowest 1000- grain weight, which were (17.2and 20.8) $\mathrm{g}$ in the first and second seasons, respectively.Similar results were stated by E-Kalla et al. (2006)

The interaction between rice cultivars and seed soaking exhibited significant effect on 1000 - grain weight of rice in the two seasons of this study (Table 3 ).The the heaviest 1000 grain weight(26.9and $25.9 \mathrm{~g}$ ) were recorded under seed soaking ZnSo4 with Sakha 104 cultivar in the first and second seasons, respectively. The lowest 1000 grain weight was( 17.88) esulted from cytokinine with Sakha 104 in the first season and with Sakha 101 under soaking seed in cytokinine( 19.89). Similar results were stated by Sedeek(2011)

Panicle length $(\mathrm{cm})$ :

The results clearly show that studied cultivars significantly affected panicle length in the first season as shown in Table 1 .The general view of obtained results clear that, panicle length significantly increased by Giza 178 cultivar as compared with other cultivar and produced the longest panicles, where results were 28.9 and $21.8 \mathrm{~cm}$ in the first and second seasons, respectively. The increase in panicle length due to Giza 178 cultivar was about $10.0 \%$ on the averages of two years over than sakha101 cultivar. These results might be resulted by genetic factors make up. These results are in line with those stated by Kalboch (1997), El-Kady and Abd El-Wahab (1999) and Sedeek (2001).

The data indicated that there were significant differences between seed classes on panicle length $(\mathrm{cm})$ only in the first season. The maximum values panicle length $(\mathrm{cm}(26.2 \mathrm{~cm}$ and $21.0 \mathrm{~cm})$ were recorded with using certified seed. but, the lowest values were $(20.1$ and 20.7$)$ by using the basic seeds in 2011 and 2012 seasons, respectively, The increased in panicle length due to certified seed class may be due to highly significant than the other seed classes, because the variance value of basic seed was higher than the value in certified seed. Bassal and Zahran (2002) and Ahmad et al. (2008) reported similar results

The statistical analysis of data indicated that panicle length $(\mathrm{cm})$ was significantly affected by seed soaking in the first season only as shown in Table 1 Rice seed soaking at $\mathrm{ZnSO}_{4}$ significantly increased panicle length $(\mathrm{cm})$ as compared with other soaking treatments The highest values, was 31.6 in the first season, El-Refaee (2002) and Ahmad et al. (2008) reported similar results.

\section{Grain yield (ton) fed :}

The results in Table 1 clearly indicated that grain yield (t/fed) significantly affected by cultivar performance in both seasons. Giza 178 cultivar gave. The maximum grain yield in both seasons, which were 3.880 and 4.170 tons/fed in the first and second seasons, respectively. Giza 178 cultivar markedly posses the most significant increase in grain yield compared with other varieties and came in the first rank. More ,Sakha 104 cultivar markedly posses the second rank as compared with Sakha 101 
cultivar On the other hand could be recommended that rice plant Giza 178 and Sakha 101 to get maximum grain yield (t/fed) at the experimental site at El-Senblawin and the superiority of Giza 178. The differences among tested cultivar in grain yield might be due to the differences in period of developing tillers in the vegetative phase and the differences in panicle length, panicle weight and number of grains/panicle. , respectively Similar results were obtained El-Kady and Abd El-Wahab(1999).Abo-youssef etal (2005)

Table 1: Means of Plant height(cm), Number of tillers, Number of grain/panicle ,Grain weight /panicle(g), 1000 - grain weight, Panicle length $(\mathrm{cm})$ and Grain yield (ton /fed) as affected by rice cultivars, seed classes and soaking in treatments during 2011 and2012 seasons.

\begin{tabular}{|c|c|c|c|c|c|c|c|} 
Chycacters & $\begin{array}{c}\text { Plant } \\
\text { height } \\
(\mathrm{cm})\end{array}$ & $\begin{array}{c}\text { Number } \\
\text { of tillers } \\
\text { /hill) }\end{array}$ & $\begin{array}{c}\text { Numberof } \\
\text { grain } \\
\text { /panicle }\end{array}$ & $\begin{array}{c}\text { Grains } \\
\text { weight/ } \\
\text { panicle } \\
\text { (g) }\end{array}$ & $\begin{array}{c}1000 \text { grain } \\
\text { weight g }\end{array}$ & $\begin{array}{c}\text { Panicle } \\
\text { length } \\
\text { (cm }\end{array}$ & $\begin{array}{c}\text { Grain yield } \\
\text { (ton /fed }\end{array}$ \\
\hline
\end{tabular}

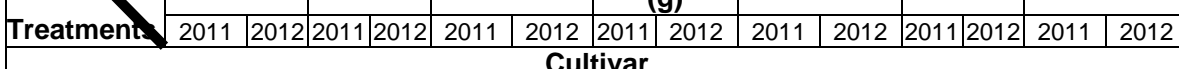

\begin{tabular}{|c|c|c|c|c|c|c|c|c|c|c|c|c|c|c|}
\hline \multicolumn{15}{|c|}{ Cultivar } \\
\hline Sakha104 & 88.2 & 90.4 & 7.9 & 8.3 & 95.1 & 98.5 & 2.7 & 2.4 & 22.8 & 23.4 & 20.9 & 19.8 & 3.361 & 3.206 \\
\hline Sakha101 & 87.2 & 85.9 & 7.3 & 7.8 & 88.5 & 79.9 & 2.2 & 2.6 & 21.8 & 22.5 & 19.7 & 20.4 & 3.220 & 3.240 \\
\hline Giza 178 & 90.6 & 92.9 & 9.6 & 8.8 & 98.7 & 101.9 & 3.6 & 2.8 & 22.7 & 19.8 & 28.9 & 21.9 & 3.880 & 4.170 \\
\hline F. test & NS & NS & * & $* *$ & NS & * & * & NS & NS & NS & * * & NS & * & * \\
\hline $\begin{array}{l}\text { N.LSD at } 5 \\
\%\end{array}$ & --- & --- & 0.73 & 0.21 & $\cdot, 0$ & $\cdot, \Lambda$ & $\cdot, \varepsilon$ & -- & -- & --- & 1,1 & -- & 0.033 & 0.044 \\
\hline $\begin{array}{l}\text { N.LSD at } 1 \\
\%\end{array}$ & --- & --- & 1.1 & • & $\cdot, \wedge$ & 1,1 & $\cdot, V$ & -- & -- & --- & $1, r$ & -- & $r, \varepsilon \leqslant$ & 1,007 \\
\hline \multicolumn{15}{|c|}{ B-seed classes } \\
\hline Basic seed & 87.9 & 89.4 & 8.5 & 8. 3 & 98.3 & 90.3 & 3. 4 & 2. 8 & 21.8 & 23.7 & 20.1 & 20.7 & 3.230 & 3.201 \\
\hline $\begin{array}{l}\text { Certified } \\
\text { seed }\end{array}$ & 81.4 & 89.1 & 7.7 & 8.3 & 84.0 & 82.8 & 2. 6 & 2. 5 & 21.4 & 22.9 & 26.2 & 21.0 & 3.080 & 3.240 \\
\hline F. test & ** & NS & * & NS & ** & NS & ** & * & NS & * & ** & NS & NS & NS \\
\hline \multicolumn{15}{|c|}{ C-soaking } \\
\hline water & 85.6 & 86.6 & 7.8 & 8.3 & 96.7 & 82.5 & 2.5 & 2.3 & 21.6 & 22.7 & 19.9 & 20.8 & 3.300 & 3.305 \\
\hline $\mathrm{ZnSO}_{4}$ & 93.8 & 91.4 & 9.5 & 8.4 & 101.6 & 101.6 & 3.9 & 2.5 & 24.4 & 23.4 & 31.6 & 23.8 & 3.820 & 4.205 \\
\hline DAP2\% & 90.4 & 86.8 & 7.3 & 8.3 & 83.2 & 81.4 & 2.4 & 2.2 & 22.9 & 23.3 & 20.6 & 19.9 & 3.210 & 3.204 \\
\hline $\mathrm{GA}_{3}$ & 83.1 & 87.6 & 8.3 & 8.7 & 87.8 & 81.5 & 2.4 & 2.1 & 21.5 & 22.9 & 21.0 & 20.5 & 3.150 & 3.190 \\
\hline cytokinine & 70.1 & 76.3 & 7.7 & 8.0 & 82.3 & 88.3 & 3.9 & 2.5 & 20.3 & 20.7 & 20.0 & 19.6 & 3.800 & 3.340 \\
\hline \begin{tabular}{|l|l|} 
F. test \\
\end{tabular} & $* *$ & * * & ** & NS & ${ }^{* *}$ & $* *$ & ** & ${ }^{*}$ & ** & ${ }^{*}$ & $* *$ & NS & ** & NS \\
\hline $\begin{array}{l}\text { N.LSD at } 5 \\
\%\end{array}$ & 1.2 & 1.1 & 0.6 & -- & 0.8 & $\cdot, 0$ & $\cdot, 9$ & $\cdot, \wedge$ & 0.6 & .8 & .6 . & --- & 0.037 & -- \\
\hline $\begin{array}{l}\text { N.LSD at } 1 \\
\%\end{array}$ & 1.4 & 1.3 & 9 , & -- & $\cdot, 9$ & $\cdot, \wedge$ & $1, Y$ & 1,1 & 0.8 & 9 & 0.8 & ---- & 0.040 & -- \\
\hline \multicolumn{15}{|c|}{ D-nteraction } \\
\hline$A \times B$ & $* *$ & ${ }^{*}$ & NS & NS & $* *$ & ${ }^{\star *}$ & NS & NS & ** & * & $\star \star$ & NS & NS & NS \\
\hline$A \times C$ & NS & NS & $\star \star *$ & * & NS & NS & $\star \star *$ & ** & ** & * & NS & NS & * & NS \\
\hline $\mathrm{B} \times \mathrm{C}$ & ** & $\star \star$ & ** & ** & NS & NS & NS & NS & NS & NS & NS & NS & NS & NS \\
\hline$A \times B \times C$ & NS & NS & NS & NS & $* *$ & ** & NS & NS & NS & NS & NS & NS & NS & NS \\
\hline
\end{tabular}

Regarding to the effect of seed classes on grain yield ( $t /$ fed)results inTable1 indicated that non significant differences were observed between basic and certified seed in the first and second seasons The result indicated 
to the response of basic and certified seed to genetic and enviromental condions under the center of El-Senblawin.

The statisical analysis of date indicate that grain yield (t/fed )was significantly affected by soaking seed in the first season only as shown in Table 1 soaking rice seed in $\mathrm{ZnSO}_{4}$ significantly increased grain yield as compared with other soaking treatment which were recorded the highest values 3.820 and 4.205 in the first and second seasons respectively while soaking seed rice in $\mathrm{GA}_{3}$ treatment recorded the lowest grain yield, which were value 3.150 and 3.190 in the first and second seasons, respectively Results were stated by Ebaid (2005) and El-Kalla (2006)

The interaction between rice cultivars and seed soaking exhibited significant the results recommended of znso 4 seed soaking to recorded the most increase the gain yield (ton/fed ) in effect on grain yield (ton). of rice in the first season of this study Table 4 . The highest the gain yield rice plants (3.570) were recorded under the seed soaking ZnSo4 with Giza 178 in the first, respectively. Whereas soaking seed treatment ZnSo4 with Giza 178 cytokinine $75 \mathrm{mg} / 1$ markedly decreased grain yield (ton/ fed)of both seasons. The lowest grain yield (ton/ fed) were resulted from GA3 (2.901) were produced from planting Giza 178 in the first season, Similar results were stated by Abo-khalifa etal (2005) and Ebaid (2005)

Table 2: Means of 1000 - grain weight $(\mathrm{g})$ as affected by the interaction between rice Cultivars and Seed classes treatments during 2011 and 2012 season

\begin{tabular}{|c|c|c|c|c|}
\hline \multirow{3}{*}{ Cultivars } & \multicolumn{4}{|c|}{1000 - grain weight } \\
\hline & \multicolumn{2}{|c|}{2011} & \multicolumn{2}{|c|}{2012} \\
\hline & Basic & Certified & Basic & Certified \\
\hline Sakha 104 & 23.9 & 23.8 & 23.7 & 23.9 \\
\hline Sakha 101 & 22.3 & 23.6 & 21.9 & 21.9 \\
\hline Giza 178 & 21.9 & 17.2 & 21.9 & 20.8 \\
\hline F. test & \multicolumn{2}{|c|}{ ** } & \multicolumn{2}{|c|}{ * } \\
\hline LSD at $5 \% . \mathrm{N}$ & \multicolumn{2}{|c|}{0.88} & \multicolumn{2}{|c|}{0.9} \\
\hline LSD at $1 \% . \mathrm{N}$ & \multicolumn{2}{|c|}{0.92} & \multicolumn{2}{|c|}{0.95} \\
\hline
\end{tabular}

Table 3 : Means of 1000 -grain weight as affected by the interaction between rice cultivars and Seed soaking treatments during 2011 and 2012 seacon

\begin{tabular}{|c|c|c|c|c|c|c|c|c|c|c|}
\hline \multirow{3}{*}{ cultivar } & \multicolumn{10}{|c|}{1000 - grain weight } \\
\hline & \multicolumn{5}{|c|}{2011} & \multicolumn{5}{|c|}{2012} \\
\hline & water & $\mathrm{ZnsO}_{4}$ & DAP & $\mathrm{GA}_{3}$ & CYTO & water & $\mathrm{ZnSO}_{4}$ & DAP & $\mathrm{GA}_{3}$ & CYTO \\
\hline Sakha 104 & 19.2 & 26.9 & 21.1 & 25.6 & 17.8 & 21.7 & 25.9 & 25.2 & 22.6 & 20.3 \\
\hline Sakha 101 & 21.8 & 26.6 & 24.9 & 20.6 & 20.6 & 20.6 & 23.7 & 21.6 & 23.7 & 19. 8 \\
\hline Giza 178 & 24.1 & 19.5 & 22.9 & 18.6 & 18.8 & 23.3 & 20.9 & 23.3 & 22.6 & 21.1 \\
\hline F. test & \multicolumn{5}{|c|}{ ** } & \multicolumn{5}{|c|}{ * } \\
\hline NLSD at $5 \%$. & \multicolumn{5}{|c|}{0.85} & \multicolumn{5}{|c|}{1.1} \\
\hline N.LSD at $1 \%$ & \multicolumn{5}{|c|}{1.0} & \multicolumn{5}{|c|}{$1 \pi$} \\
\hline
\end{tabular}


Table 4: Means of Grain yield (ton / fed\} as affected by the interaction between rice cultivars and soaking treatments in during 2011 seasons

\begin{tabular}{|l|c|c|c|c|c|}
\hline \multirow{2}{*}{ soaking } & \multicolumn{5}{|c|}{ Grain yield (ton/ fed) } \\
\cline { 2 - 6 } cultivar & water & Znso 4 & DAP & $\mathrm{GA}_{3}$ & CYTO \\
\cline { 2 - 6 } & 3.420 & 3.520 & 3.320 & 3.250 & 3.030 \\
\hline Sakha 104 & 3.340 & 3.260 & 3.010 & 3.290 & 2.910 \\
\hline Sakha 101 & 3.130 & 3.570 & 3.290 & 2.910 & 3.150 \\
\hline Giza 178 & \multicolumn{5}{|c|}{0.080} \\
\hline F. test & \multicolumn{5}{|c|}{0.130} \\
\hline LSD at 5\%. N & \multicolumn{5}{|c|}{} \\
\hline LSD at 1\%. N & \multicolumn{5}{|c|}{} \\
\hline
\end{tabular}

\section{REFERENCES}

Douglas, J. G. (1980). Successful seed programs: A planning and management guide. Westview Press Inc. 500 Central Avenue, Boulder, colorado 80301, US.

Zayed, B.A. ; A.A.M. Abd El-Rahman, A.K.M. Salem (2005). The effect of different farmyard manure levels and different modes of urea application on rice productivity under salt affected soil. Egypt. J. Agric. Res., 2(2) 631-642.

Bassiouni .S.M.A.,B.A.Zayed. A.A.E.Mohamed and ,A.A.Omar (2011) effect of $p$ er-sowing seed and seedling treatment on growth and yield of Egyptian hybrid rice under saline soil conditions J.Agric Res kafer

Abdel -Hafez, A.G:M.I. Abo- Youssef: E.E.EL-Sharef and H.Sh.Hamad 2005 Effect of sowing date and growth regulators on rice hybrid seed quality and seedling characters th onf of Agronomy Agron.Dept.,Fac.Agric,Assiut Univ 223.

EL-Ekhtyar A.M.:B.A.Zayed; A.A. Abd Allah ;A.B. EL-Abd and A. F. A.f.Abdelkalik (2008) pre sowing seed treatment related to seedling vigor grain yield of egyption hybrid rice Agric. Sci. Mansoura Univ., 33(11): 7759-7769.

Waller, R. A. and D. B. Duncan (1969). A bays rule for symmetric multiple comparison problem. Amer stat. Assoc. J. 1485-1503.

El-Sheref, T.E. ; M. Haleem ; A. Galelah and M. Abd El-Hameed (2004). Effect of nitrogen levels, hill spacing and rice cultivars mixtures on some rice characters. J. Agri. Sci. Mansoura Univ., 29 (2): 535-552.

El-Refaee, I.S.H. (2002). Studies on irrigation systems for some rice cultivars. Ph. D. Thesis, Fac of Agric., Kafr El-Sheikh, Tanta Univ., Egypt.

Singh, S. (2005). Effect of low-light stress at various growth phases on yield and yield components of two rice cultivars. Intern. Rice Res. Notes, 30(2): 36-37

El-Kalla, S.E. ; E.M. Said ; A.A.M. Abd El-Rahman and A.M.S. Kishk (2006). Response of rice cultivars to irrigation intervals and some organic fertilizer treatments in newly reclaimed soils. J. Agri. SciMansouraUniv,31(9) 5547-5555. 


\section{EL-Kalla, S. E. et al.}

Sedeek, S.E.M.(2001). Studies of morphological and agronomical characteristics of some early varieties and lines of rice.M.Sc.Thesis, Fac. of Agric.TantaUniversity.

Draz A.E.; M. I. Abo-Youssef and A. El-kady (2003). Rice seed production over rice integrated crop management system for food security in Near East Countries.27-29 July, 68-81.

Ahmad, S.M. ; H. Ziaul ; H. Ali ; S.A. Shael ; A. Ahmad ; M. Maqsood ; M.B. Khan ;S.Mehmoodand A.Hussain (2008).Water and radiation use efficienciesof transplanted rice Oryza sativa L.at different plant densities and irrigation regimes under semi arid environment. Pakistan J Bot.,40 (1): 199-209.

Hasanuzzaman, M. ; M.L. Rahman ; T.S. Roy ; J.U. Ahmed and A.S.M. Zobaer (2009). Plant characters, yield components and yield of late transplanted Aman rice cultivar as affected by plant spacing and number of seedling per hill. Adv. Biol. Res., 3 (5-6): 201-207

Abo Youssef, M.I.;Sorour,S.gh.Abdelkrem,M .Z and M.A.Tawfik( 2011) the effect of seed classes on the productivity of some rice cultivars J,Agric. Res kafer EL -sheikh Univ., (2)

Abd Allah, A.A(1996).Effect of some cultural treatments on rice. M. Sc. Thesis, Fac. of Agric., Moshtohor, Zagazig Univ.,(Banha Branch),Egypt.

Kalboch, F.A.M.H.(1997).Agronomic studies on rice. M.Sc. Thesis, Agron. Dept., Fac. of Agric., Mansoura Univ., Egypt.

Bassal, S.A.A. and F.A. Zahran (2002). Effect of farmyard manure, bio and mineral nitrogen fertilizer and hill spacing on rice crop productivity. J. Agric. Sci. Mansoura Univ., 27 (4): 1975-1988.

El-Kady, A.A. and A.E. Abd El Wahab(1999).Nitrogen fertilizer management and its effect on growth, yield and grain quality of some Egyptian rice. Egypt. J. Appl.Sci.,14 (7): 26-35

Abo-Youssef,M.I.;A.G. Abdel -Hafez;E.E.EL- Sharef and H.Sh.Hamad (2005). Effect of sowing date and growth regulators on hybrid seed productivity two promising rice hybrids under Egyptian conditions .Eleventh conference of Agronomy ;Agron .Dept., Assiut Nov. 15$16: 235-249$

Ebaid, R.A. (2005) performance of brooadacast seeded rice sakha104 under different nitrogen levels and zinc methods of opplication in egypt $j$ agric res $83(5 b)$ 


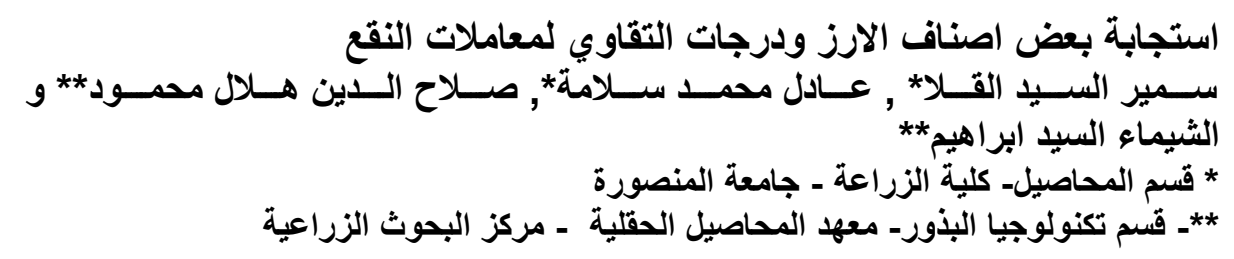

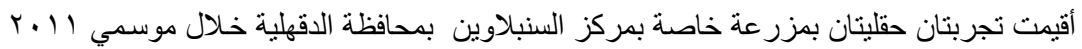

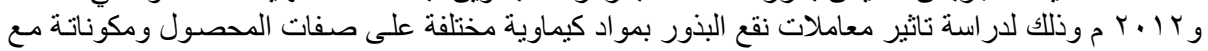

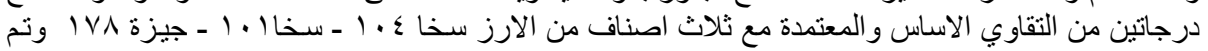

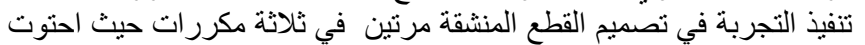

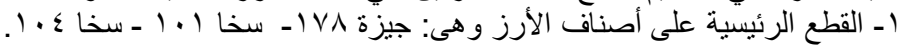

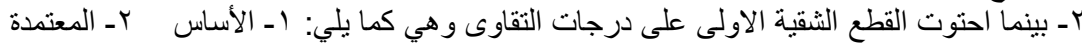

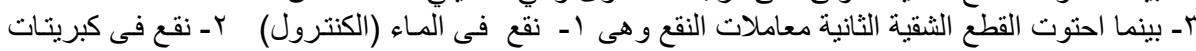

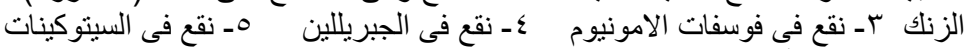

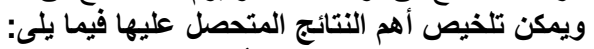

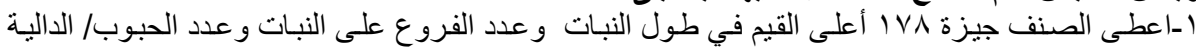

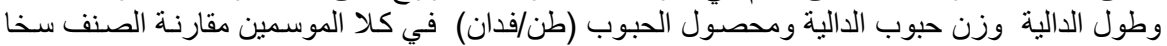

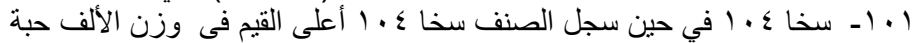

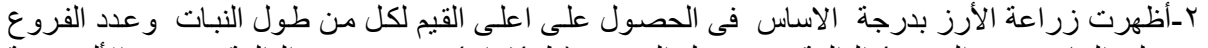

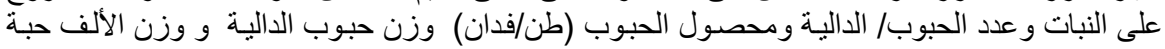

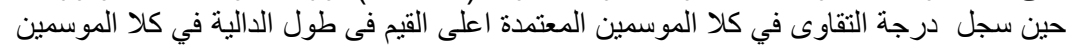

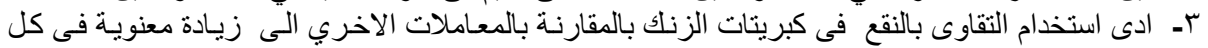

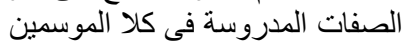

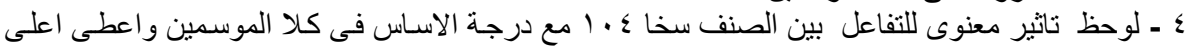

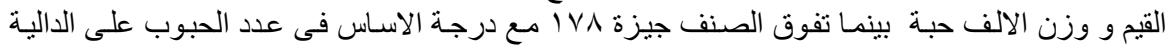

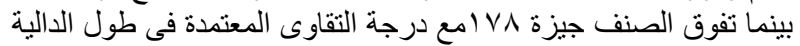

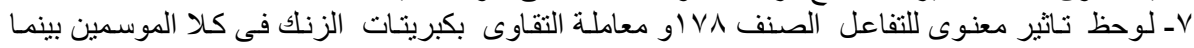

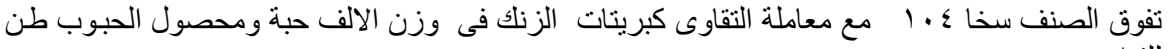
للفدان

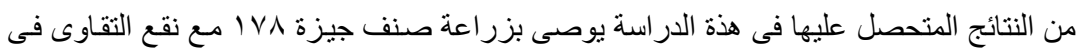

كبريتات الزنك وذللك تحت ظروف محافظة الدقهلية.

كلية الزراعة الزراعة - جامعة كفر المنصورة الشيخ
قام بتحكيم البحث

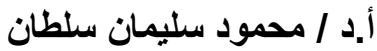

أ.د / محمد سعد عبد العاطى محلى سئن 